\title{
Every Five Years
}

National Cancer Institute

\section{Source}

National Cancer Institute. Every Five Years. NCI Thesaurus. Code C161334.

Planned or occurring every five years. 